\title{
THE EFFECTIVENESS OF FINANCING MODEL TO SUPPORT COMPETITIVE ADVANTAGE IN CERAMIC INDUSTRY
}

\author{
Elizabeth Tiur Manurung \\ eliz@unpar.ac.id \\ Universitas Katolik Parahyangan
}

received: 23/9/2019; revised: 16/10/2019; published: 30/10/2019

\begin{abstract}
The Micro, Small, and Medium Enterprises (MSME) sector is not an easy sector to obtain credit from Bank/Financial agent, because too many obstacles to a access Bank credit, such as: collateral, administrative aspect, company stability. The purpose of this study is to implement an effective financing model for ceramic craftsmen, in relating with achieving competitive advantage of pottery Plered craftsmen. By using descriptive method, research result shows The effectiveness of funding model for ceramic craftsmen that consist of 4 elemens, such as: local government of Plered, Ceramic craftsmen, Financial agency, and Deposit insurance agency; which is all elemens shoul be made a well-coordinated. The effectiveness of financing aspects in ceramics industry, encouraging the development of ceramics production and also craftsmen productivities. Company productivity will increase too. It means product sustainability of pottery industry will be achieved and competitive advantages of ceramic Plered will be increased.
\end{abstract}

Keywords: micro; small; medium; enterprise; bank credit; competitive advantage; ceramics product 


\section{INTRODUCTION}

The impact of the systematic economic crisis in Indonesia occurred in 2008/9 has resulted in unavoidable bankruptcy for a lot of big companies that failed to maintain its operation. But this is not the case for Micro, Small, and Medium Enterprises (MSMEs) which are more resilient to crises because they do not use many imported materials in their business. The information from banking sector shows that the fund channelled to the MSME sector have ben returned smoothly, and does not cause a large non-performing loans. The ratio of non-performing loans to funds channelled to MSME sector is around 2\%-3\% (Manurung et. al, 2009).

The economic crisis also caused the MSME sector to face a sharper business competition, so that the planned profits of the company can only be achieved with great effort. Important efforts undertaken by the company, for example increasing the capital to develop their operation and productivity. As stated by William et. al (2015), capital is one of the most important aspects in a business enterprise.

In fact, it is not easy for MSME sector to obtain additional capital from either the Bank or the non-bank financial institutions due to various obstacles faced by this sector, for example administrative aspect, collateral requirements, business guarantee constraints, unstable business, and so on. The people of MSMEs really expect the convenience in applying for credit to the bank, with collateral and fairly low interest rate. In Europe, to overcome the difficulty of making financial reports for small company, a simplified form of reporting standards for small business have been created. (Zagera and Decman, 2016).

Some problem similar to that, especially in the ceramic industry, various obstacles in obtaining funding sources must be solved so that the ceramic industry can develop its business and can achieve its competitive advantage. The result of empirical research conducted by Altasseb and Karunakaran (2016) states that in Pakistan, the Akuhuat financial institution has a significant impact on capital and profitability of Micro businesses.

The Ceramic industry, such as in Plered, can access additional capital quite easily, so it can develop its business operations optimally, in terms of the quality of ceramic materials, product quality, competitive prices, better service to customers, speed and accuracy of delivery goods, so the business' productivity could increase. The increase in business profitability push the company to achieve more competitive advantage, thereby increasing the income of the industrial community (William et al. 2015). If ceramics become superior product, and can be developed better, the company can improve more, as quoted by Brigham and Daves (2013) "a corporation grow generally from internal expansion, through the creation of development division" means there are business growth and increased market share for products. This can be followed by the superiority of the company's better product. This explanation is the basis why this study is conducted with the topic how the availability of financing in the ceramic industry in Plered can support the achievement of higher competitive advantage over ceramic products.

Indonesia has many very rich natural resources. If the natural resources are managed by ourselves well, then all the results can be utilized for our mutual benefit as well, so that the community's economy becomes independent with a good quality of life. ndonesia's population is very large, the scale of manufacturing businesses and other businesses are also carried out with a large scale, which also allows to produce great efficiency so that the product produced is a superior product that can penetrate the competitive market (Manurung, 2009).

Every region in Indonesia has different potential advantages. If each of these advantages is developed well, then the superior product can increase its competitiveness in the market (Brigham and Daves, 2013). Residents in each region also have a good understanding of the culture in their area, they are very familiar with the region, culture and art, social conditions, which have been done and become daily habits. So, each region already has human resources that have characteristics that are following the industry's needs in the region. In relation with competitive advantage, Delery and Dorothea (2017) stated that The resource-based view of the firm has been consistently used as a backdrop in strategic human resource management research and has the potential to bridge the 'micro-macro' devide. Other research result about competitive advantage in relating with performance, like Jardon and Martos (2012), stated The competitive advantage scheme in emerging cluster of SMEs proposes that resources affect organizational capability territory and organizational capabilities affect strategic factors which improve performance.

In the ceramic industry, adequate supporting programs are also needed, for example: (1) to develop this industry, adequate gas supply is needed; (2) improve product quality in accordance with national certificates; (3) coordinating with regional governments to develop ceramics as an industry of regional excellence, in particular the availability of domestic raw materials; (4) opportunity as a priority industry (Penjelasan Peraturan Presiden RI No. 28/2008).

Plered ceramic industry clusters are generally managed by micro and small entrepreneurs. The definition of micro, small and medium business, stated by the Central Statistics Bureau (2010) is a business unit, which is managed by a small number of employees, the total assets or asset turnover is also quite low. While the characteristics of micro and small businesses, including (1) allocation of a small number of 
resources; (2) does not have an accounting department so that the business records are inadequate; (3) limited separation of functions; (4) the owner usually has roles as a manager too (Manurung; 2009).

\section{METHODS}

This study uses descriptive methods (Sekaran, 2016), researching and describing the characteristics of each research variable in a particular condition. The purpose is getting the validity of used data, proving and developing the comprehension of knowledge, anticipating problems and the solutions. The steps begin with data processing, analyzing, interpreting the result based on systematic discussion along with arranging the appropriate conclusion.

The corresponding general and specific criteria in the descriptive research method are: general criteria - there are the relevance of problem arrangement, the purpose is formulated clearly, the used data are valid facts, if the standard uses as a comparison then the validity of data must be accepted. Whilst the specific criteria - in example the data that is used must be valuable, as well being a manager concurrently (Manurung, 2009).

Fact and principle that would be the subject of discussion. The descriptive research's nature is ex post facto which means there is no certain manipulated and controlled variable that is being researched.

The object of research uses ceramic industry entrepreneurs in the City of Plered. The steps taken are described as follows: (1) determining the research topic; (2) determining the object of research, namely ceramic business craftsmen are 150 persons in this sample in Plered City, and determining the variables studied, such as (a) Ceramic as superior products ; (b) effective financing shown with low interest rate and higher credit level; (c) ceramics industry as the industry with the highest local community participation; (3) searching for theories in related literature; (4) Data collection techniques are carried out both based on interviews to obtain primary data and secondary data through related publications and through searching journals; (5) Data analysis techniques used are through comparison with related theories and the results of previous studies so that the result of the comparison can be used to draw conclusion; (6) make conclusions based on the discussion in step 5 before. As a comparability there are some research in ceramic industry area as a research object, Muina et. al (2018) conclude the paper explores the phases of the transaction from a linear to circular economy and proposes a procedure for introducing the principles of sustainability in a manufacturing environment. And Biswas (2019) concluded a few of the sample companies show positive and a few show negative correlation between ROE and the ratios of capital structure.

\section{RESULT}

Based on the results of observation and interview with Plered ceramic businessmen, an understanding of ceramic business in Plered has been obtained, that in the 1970s ceramic business in Plered started receding. According to the ceramic businessmen, the cause is the tedious design, and they realized to increase innovation of their products, together with the demand for additional capital to develop products corresponding to customer's taste.

Other observation results are the obstacles related to the financing of ceramic industry, as follows: (1) the bureaucratic obstacle reduces access of UMKM to get credit; (2) requirement to submit financial report; (3) there are not sufficient assets to be guaranteed; (4) the limitation of financial institution or bank that could give credit, in example: there is only BNI in Plered; (5) shortcoming of information between UMKM with the finance provider; (6) the needing of effective financing scheme particularly for Plered ceramic businessmen.

According to observations and interviews with ceramic companies in Plered, only 4\% create their financial statements. Their financial statements are very simple, some companies create simple records about operational expenses, but not systematic, and most of the companies do not have records. In order to create good financial statements, other parties like universities need to guide ceramic companies in Plered about the preparation of financial statements in a simpler form. According to Zagera and Decman (2016), in Europe, the financial statements for micro and small enterprises have a simpler form than for large companies or corporations. Even though they have a simpler form, they can record all company transactions in a structured manner.

$69 \%$ of respondents of ceramic companies in Plered hope the financing model from the bank has an interest rate lower than $16 \%$ in a year; $15 \%$ of respondents hope a shorter payment period and the remaining $16 \%$ of respondents hope for a higher credit limit.

\section{DISCUSSION}

The research findings of the obstacles of credit access for the ceramic companies in Plered, similar with Saraswati's research (2014), generally, microentrepreneurs face some obstacle while obtaining funds from the bank such as: (1) administrative obstacle, (2) insufficient guarantee amount, (3) business stability, (4) High interest rate, (5) desire of non-collateral loan. Meanwhile, according to Thaken (2018), the obstacles for micro, small, and medium enterprises to access funds to the bank are the type of micro, small, and medium enterprises, the management, and fulfillment of requirements in obtaining funds.

The appropriate financing development for the ceramic companies in Plered is using the support from 
the Bank of Indonesia (BI) program. BI, as the Authority has a role in supporting Bank intermediary function, especially in distributing funds for micro and small entrepreneurs. The distribution of effective financing for the ceramic companies in Plered can be used to develop ceramic products quality which is more competitive in the market. This result has a little bit different with the result of Turoczy and Marian (2012) that conclude Self-financing capacity, return on equity, and degree of technical endowment has significant impact to size of profit.

Explanation of scheme 2 above, is as follows: (1) The rural and local government have functioned as a facilitator in forming new businesses such as startup companies, as well as assisting promotions to increase the regional potential; (2) there is assistance from the technical team that helps to assess whether the craftsmen are a prospective debtors. Analyst team assesses based on 5C (Character, Capacity, Capital, Collateral, Conditions), with maintaining the carefulness principle, considering adequate business along with debtor's ability. The technical team also has a function to give accompaniment, for example make a simple financial report. In this step, it could involve the role of cooperative to have a role as a recommender to a bank about which decent debtor is given credits. Similar to the research result by Anam and Nahar (2015) that concludes if a cooperative is a form of the best business to manage microfinance, so as could be finance institution for micro and small business; (3) Credit guarantee agency likewise expected could guarantee approximately $70 \%$, so that the loss percentage that is unguaranteed would be somewhere $30 \%$; (4) supposed there is socialization to public about the aspects of credit requirement, for example, the credit duration - the interest rate of loan is proposed between $4 \%$ until 12\%on interest and debt installment- it is raised up until 50 million- the amount of assurance- there is management change- prohibition to transfer assurance to another party - requirement of financial report- the transfer of business development report. The explanation in the 4th point is similar to Fitriasari's research (2017) that could be concluded if banks have the ability to solve the problem of micro and small businesses, along with supporting the development of cooperative until the ability and the eminence of the micro and small sector could develop.

A product could be superior if meets the requirements. Plered is a city with the richness of special natural resources that aren't owned by other regions, for example, the high-quality clay makes ceramic products with the high-quality too. Furthermore, people live in Plered have the experience, craftsmanship, and talent in managing ceramic industrial, along with the hot weather could help to dry the ceramics, Indonesian's opinion state if Plered has the ability to produce the remarkable high-quality ceramics. All of the factors above support the achievement of ceramic products that are produced with high quality, so it is not exaggerated if it is concluded the ceramic is a superior product in Plered.

The result of the explanation above, according to the research by Harny Ezo (2015), that explains if the competitive region product is a product or service that is owned and controlled by the region, which has economic value-added, has high competitiveness, also absorbs a considerable amount of labors, the product that is produced using the raw material from its region and has owned the market, and supported by the community and the regional rural institutions. Similar with research result by Coff and Kryscynski (2011) to make the competitive advantage of a city sustainable, the human aspect as capital is very important.

The regulations of the Indonesian Republic domestic minister No. 09 (2014), stated if the potential development of regional economic corresponding to the superior products in the region, so as the regional economic develop efficiently; and the competitiveness of regional product might increase and the investment goes to the region gets greater.

The 3rd schema down below shows the relation between effective financing with the improvement of competitiveness in ceramic industrial.

Scheme 3 explains the effective financing channeled to the Plered ceramics industry can develop the competitiveness of ceramics products, because the products produced are attractive to customers; one of the methods carried out in developing Plered ceramics is through market observations aimed to know market tastes. This method requires greater funding, for the addition of equipment, the addition of new employees, and the addition of raw materials needed. In other words, effective financing will result in higher productivity.

As a result of product development, it is increasingly confirmed that Plered is a producer of ceramics with good quality, attracts more customers and has increased business productivity, so ceramics become superior products. This research is in line with the results Anggraeni et. Al's (2013) research who concluded that effective financing in this case the BMT TadbirulUmmah microfinance institution in Bogor had a positive impact in developing MSME businesses, namely the average operating profit increased $6.21 \%$, similar to the results of the study, in North Sumatra, Prayogi and Siregar's (2017) research results also conclude that microfinance institutions have a significant positive impact on the level of company development in North Sumatra. Next, the increased business productivity supports the increasing competitiveness of products in the market.

\section{CONCLUSIONS}

Based on the results of the discussion it can be concluded, that: (1) obstacles encountered include: (a) 
bureaucracy; (b) ability to prepare financial statements; (c) inadequate amount of collateral; (d) limited funding institutions; e. weak networks between MSMEs and with banks, (2) an effective financing model is proposed as follows: (a) The rural government becomes the facilitator of the formation and promotion of the establishment of new businesses, (b) having a Technical Team to help assess potential debtors, (c) it is expected that there will be socialization to the public about credit requirements, (3) Effective financing, can encourage the development of ceramic products that have high competitiveness and increased business productivity.

The highly competitive production of ceramics from Plered City, requires better promotion so that its sales also increase, this is the next research that can be done by all parties concerned.

\section{REFERENCES}

Altasseb, Habtamu Getnet and R. Karunakaran. 2016. Emerging Micro Financing Model and Its Impact on Business Performance. IOSR Journal of Economics and Finance (IOSR-JEF) Vol 7, Issue 3 Ver IV (May-June 2016). E-ISSN: 2321-5933; p-ISSN: 2321-5925; pp 15-23.

Anam, A. Khoinul dan Aida Nahar. 2015. Identifikasi Model Pembiayaan usaha Kecil dan Menengah oleh Lembaga Keuangan Mikro di Kabupaten Jepara. www.download.portalgaruda.org/article. php? article $=320907 \&$ val.

Anggraeni, L., Puspitasari, H., El Ayyubi, S. and Wiliasih, R., 2013. Akses UMKM terhadap pembiayaan mikro syariah dan dampaknya terhadap perkembangan usaha: Kasus BMT Tadbiirul Ummah, Kabupaten Bogor. Al-Muzara'ah, 1(1), pp.56-67.

Biswas, B., 2019. The Relation Between Capital Structure and Profitability of Some Selected Companies in Indian Ceramic Industry. IUP Journal of Accounting Research \& Audit Practices, 18(3).

Brigham, E.F. and Daves, P.R., 2013. Intermediate Financial Management. 11 th edition; United Stated: South Western, Cengage Learning.

Coff, R. and Kryscynski, D., 2011. Drilling for microfoundations of human capital-based competitive advantages. cognitive perspective on the joint effects of relationship quality and differentiation on creativity. Academy of Management Journal, 53, pp.1090-1109.

Delery, J.E. and Roumpi, D., 2017. Strategic human resource management, human capital and competitive advantage: is the field going in circles? Human Resource Management Journal, 27(1), pp.121.

Ezo, Harny. 2015. Produk Unggulan Daerah sebagai Daya saing Daerah. Makalah Kebijakan Fiskal dan Moneter-2015. Harnyezo58.blogspot.com/2015/07/ makalah-unggulan-daerah-sbg.html.

Fitriasari, F., 2017. Strategi Pengembangan Pembiayaan Usaha Mikro Kecil Dan Menengah (UMKM) Di Indonesia.

Garcia-Muiña, F.E., González-Sánchez, R., Ferrari, A.M. and Settembre-Blundo, D., 2018. The paradigms of Industry 4.0 and circular economy as enabling drivers for the competitiveness of businesses and territories: The case of an Italian ceramic tiles manufacturing company. Social Sciences, 7(12), p. 255 .

Jardon, C.M. and Martos, M.S., 2012. Intellectual capital as competitive advantage in emerging clusters in Latin America. Journal of Intellectual Capital.

Manurung, E.T., 2011. Peningkatan kualitas keunggulan daerah berbasis pengembangan internal business process untuk menghadapi bisnis global ASEAN 2015.

Manurung, E. T., Widjojo, R., Fettry, S., 2009. Penyaluran Kredit UMKM melalui Model Pembiayaan UMKM yang Efektif untuk Sentra Keramik Plered. Hasil Penelitian Hibah DIKTI No. 042/SP2H/PP/DP2M/ IV/2009.

Saraswati, Ktt. 2014. kttsaraswati.blogspot. com/2014/09/contoh-komoditas-unggulan-daerahsebagai-potensi-sumber daya-alam. Indonesia.html.

Sekaran, Uma dan Rouger Bougie. 2016. Edisi 7. Research Method for Business: A Skill-Building Approach. New York: John Wiley \& Sons Inc.

Thaker, M.A.B.M.T., 2018. A qualitative inquiry into cash waqf model as a source of financing for micro enterprises. ISRA International Journal of Islamic Finance.

Peraturan Menteri Dalam Negeri Republik Indonesia No. 09 Tahun 2014; tentang Pedoman Pengembangan Produk Unggulan Daerah Jakarta- 2014.

Peraturan Presiden No. 28 Tahun 2008 tentang kebijakan industry Nasional. Jakarta 2008.

Prayogi, M.A. and Siregar, L.H., 2017. Pengaruh Pembiayaan Mikro Syariah Terhadap Tingkat Perkembangan Usaha Mikro Kecil Menengah (UMKM). Ekonomikawan: Jurnal Ilmu Ekonomi dan Studi Pembangunan, 17(2), pp.121-131.

Statistics Center Birou. 2010. Small-scale Manufacturing Industry Statistics. Statistics Center Birou: Jakarta

Turoczy Z, L. Marian. 2012. Multiple Regreeion Analysis of Performance Indicators in Ceramic Industry. Procedia Economics and Finance Journal.

Williams JR., SF Haka, MS Bettner and JV Carcello. 2015. Financial and Managerial Accounting: The Basis for Business Decision. 16th edition; McGrawHill Education, New York.

Zagera, Katarina and NikolinaDecman. 2016. Guidelines and Recommendations for Improving the Micro Entities Model of Financial Reporting. Procedia Economics and Finance 39: 451-457. 


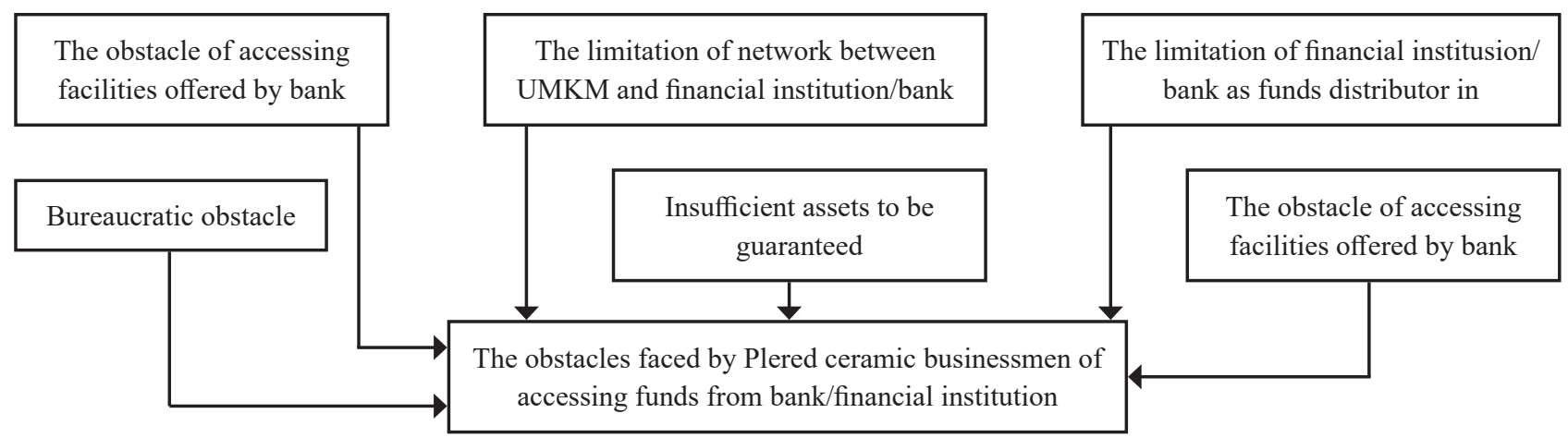

Sources: Observations and interviews with ceramic companies in Plered.

Figure 1. Obstacles of credit access for the ceramic companies in Plered.

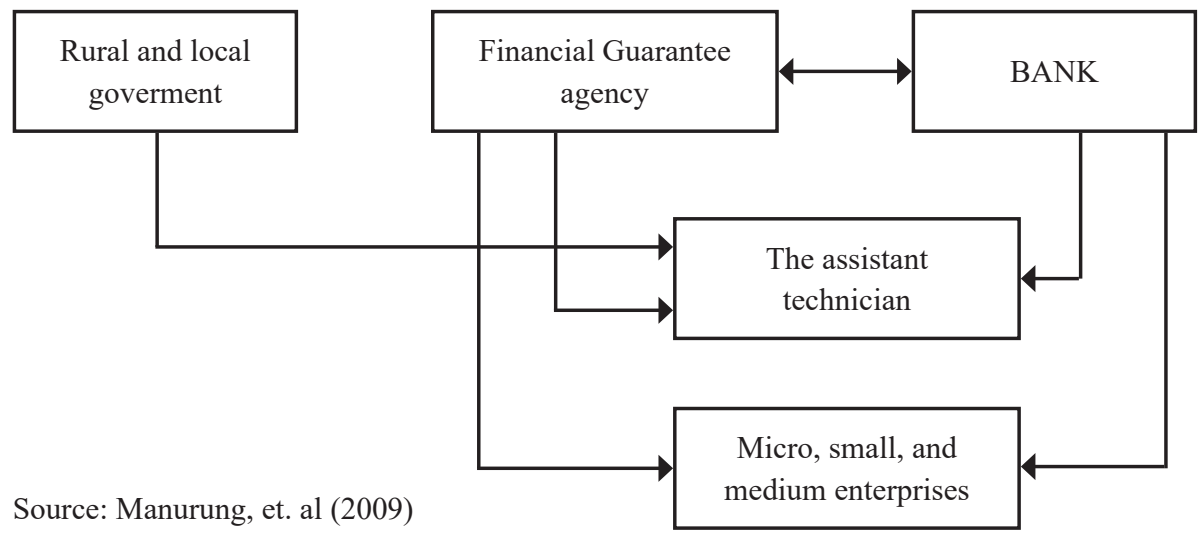

Figure 2. Effective financing model for ceramic companies in Plered

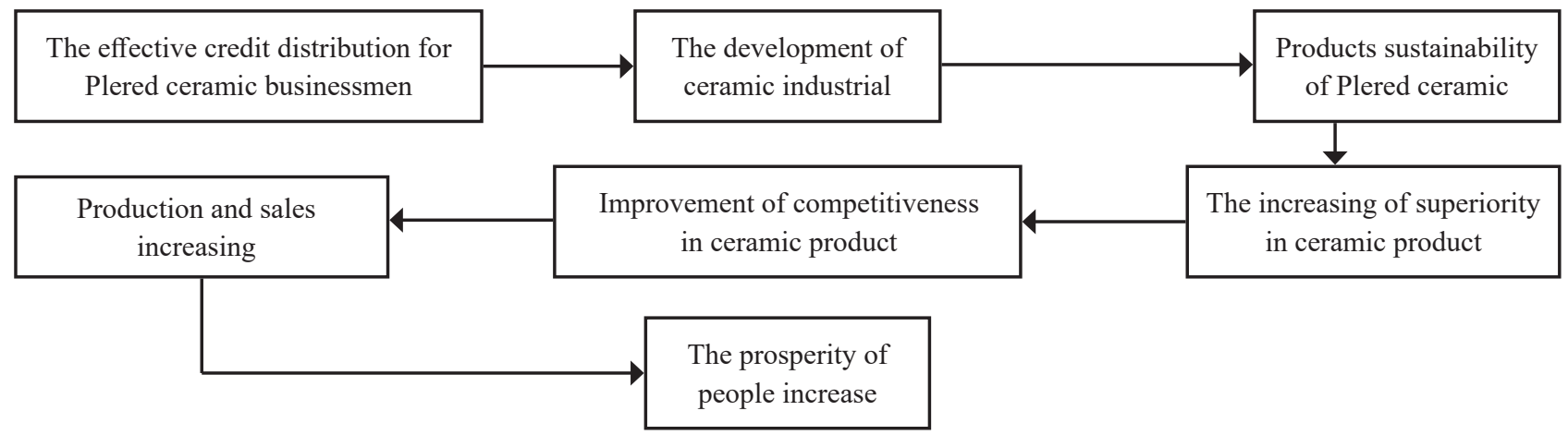

Source: The results of analyzing based on profound observation and interview with craftsman

Figure 3. The Relation of Effective Financing with Increasing Competitiveness 